Scientific workers who will take the trouble to examine the material now available, in these three books and elsewhere, cannot fail to realize how wide is the field awaiting the application of the scientific spirit and the scientific method, or to find some section of the field in which their own contribution might be made to national defence and security, and the development of that educated opinion upon which alone all constructive effort must rest.

\title{
Ancient Buildings in Scotland and England
}

$\mathrm{T}^{\mathrm{H}}$ HE discussion which took place in the House of Lords on December 2, when the question was raised as to the preservation of ancient structures in Scotland and England, while achieving little in the way of immediate action, the motions upon which debate arose being by leave withdrawn, was far from abortive. It served emphatically to direct public attention to an irretrievable loss of material of historic or æsthetic value, especially in Scotland, and in the replies elicited from the representatives of the Government, afforded hope of official support and co-operation in the efforts which are being made to avert further destruction, even though the prospects of financial assistance from the Treasury are not encouraging.

The debate was, perhaps, most useful in clearing the way for further action and in suggesting lines along which further effort might be directed. The problems in the two countries, though very similar, are not identical. Whereas in England the question before the House was concerned only with structures of the eighteenth century, in Scotland material surviving from the whole historic period is affected. In both instances, however, the structures are not 'historic' in the technical sense, or 'country houses', but examples of humbler domestic architecture - a class of building which in both rural and urban areas is of special importance for the cultural history of Scotland, where the strongly marked individuality of the people clearly has been affected distinctively by environmental influences. It was pointed out by Lord Hamilton of Dalzell and other members of their Lordships' House, who supported him, that during the last few years destruction has been taking place in Scotland wholesale and at an extremely rapid rate. "Old Scotland," said Lord Crawford, "is vanishing before our eyes."

The tragedy of this destruction lies in the fact that so often it is avoidable, but is justified as a public improvement, or amelioration of social conditions-road-making or widening and the improvement or extension of housing accommodation for the poorer classes. In Scotland, more especially, Government financial assistance has been made available in a form which has acted as a spur to the destructive activities of local authorities, while the private owner, suffering under a public burden in the form of rates-payable in Scotland on empty property-has sought relief from an expense without return.

In his sympathetic reply on behalf of the Government, Lord Strathcona pointed out methods by which complete destruction of buildings worth preservation might be avoided without forfeiting assistance from the Treasury in certain classes of property, and indicated the extent of departmental supervision already exercised in endeavouring to secure that no historically interesting building should be demolished. The financial obligation, however, involved in any promise of financial assistance from the Government towards the cost of preservation is an uncertain factor, and the delay for which Lord Strathcona asked until the information now being collected by the National Trust is available, though unfortunate, is not unreasonable.

The First Commissioner of Works (Lord Stanhope), in dealing with the position of the eighteenth-century house in England, was less sympathetic, and in suggesting that effort should be directed to persuasion of the local authority, upon whom he sought to throw responsibility, he ignored past experience. For their notorious shortcomings in such matters, local authorities are not entirely to blame; and the time has surely come when the public may be regarded as sufficiently instructed in the value of its ancient treasures to accept the overriding verdict of a Department which speaks with full scientific and technical knowledge. The powers of the Office of Works as a protector of ancient structures should be enlarged to cover in some measure inhabited or habitable structures not contemplated in existing provision. 